Small businesses are not well-catered for in terms of high-quality information. The vast majority of books written on small businesses are very basic and make scant use of modern quantitative techniques. This new series is designed for those taking courses on small businesses in universities, polytechnics and colleges and those working for professional, accounting and banking examinations.

The books, which will also attract an audience of well-informed managers and managers of growth and high-technology small businesses, will treat the major functional areas of business operations. They reflect the belief of the editors and their authors that small businesses make a substantial contribution to the economy, and that, with good management information, the contribution they make could be much greater.

PUBLISHED

Jim Dewhurst and Paul Burns, Small Business: Finance and Control

FORTHCOMING

Jim Dewhurst and Paul Burns (eds), Small Businesses in Europe Terry Hill, Small Business: Production Operations Management 


\section{SMALL BUSINESS}

Finance and Control

Jim Dewhurst and Paul Burns

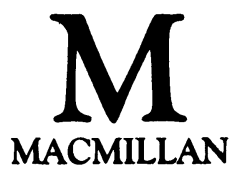


ㄷ Jim Dewhurst and Paul Burns 1983

All rights reserved. No reproduction, copy or transmission of this publication may be made without written permission. No paragraph of this publication may be reproduced, copied or transmitted save with written permission or in accordance with the provisions of the Copyright Act 1956 (as amended).

Any person who does any unauthorised act in relation to this publication may be liable to criminal prosecution and civil claims for damages.

First published 1983

Reprinted 1985

Published by

Higher and Further Education Division

MACMILLAN PUBLISHERS LTD

Houndmills, Basingstoke, Hampshire RG21 2XS and London

Companies and representatives

throughout the world 


\section{Contents}

Acknowledgements

vi

Preface

vii

\section{PART I SMALL BUSINESSES}

1 Introduction 3

2 Setting up a Small Business $\quad 10$

3 Policy for the Small Business 47

\section{PART II FINANCING AND TAXATION}

4 Financing Methods - Bank Finance 73

5 Financing Methods - Risk Capital and Government Schemes 95

6 Taxation and Allowances $\quad 117$

\section{PART III INFORMATION FOR DECISIONS}

$7 \quad$ Basic Accounting and Accounting Systems 153

8 Costing 181

9 Financial Planning and Control through Budgets 210

10 Understanding Financial Information 243

\section{PART IV FINANCIAL DECISIONS}

11 Alternative Choice Decisions: Risk and Uncertainty 271

12 Capital Investment Appraisal for Small Businesses 293

13 The Management of Working Capital 321

\section{PART V THE FUTURE}

14 Summary, Conclusions and the Way Ahead 343

Select Bibliography 359

Addenda to Chapters 2 and 6: New Advice Agencies; 1983 Budget Proposals 363

Index 369 


\section{Acknowledgements}

The authors and publishers wish to thank the following who have kindly given permission for the use of copyright material:

The Controller of Her Majesty's Stationery Office for the table from The Financing of Small Firms, Cmnd 7503, March 1979.

Jeffry A. Timmons for the Outline to his Preparing a Business Plan from New Venture Creation (1977) by Timmons, Smollen and Dingee. 


\section{Preface}

In all the short history of modern business there is nothing so strange as this. On the one hand we have the traditional belief in the rightness and power of size. Rationalisation, standardisation and concentration are the watchwords. Economies of scale rule the industrial world. In the United Kingdom we say we must be big to stand up against the ruthless cost-effective multinational corporations based in the USA and Japan. And indeed in the United Kingdom we have gone further along this road of concentration than any other country in the world. Yet this predilection for economic orthodoxy has not brought us economic success. And even some economic theory is now emphasising the diseconomies of scale.

There is another viewpoint which has a growing number of adherents. Perhaps, these people argue, economic success is not the sole criterion by which we should judge all things. Perhaps people matter. Perhaps a society should be concerned to some extent with the quality of life, job satisfaction and good human relationships. Much evidence is now produced that some primitive races are more relaxed, more caring and (unbelievably!) apparently happier than we are. Some evidence has been produced recently that people working in small business units in a civilised society are more committed than those working in large, amorphous, corporations.

One extreme conclusion we might draw from this is that we should reject our modern way of life and try a return to some primitive pre-industrial society. This is absurd. Man (but please see the sexual disclaimer later in this preface!) has competitive, striving, basic urges in his make-up. Put another way the average man in the United Kingdom - in so far as he exists - does not want to see us 'deteriorate' back into some third-rate primitive society.

What are the alternatives? One solution, ably put by Fritz Schumacher, is that an intermediate technology should be developed. 
To use his own words, this would be a technology that is 'simpler, very much cheaper, very much easier to maintain than the highly sophisticated technology of the modern West'. But the question to which he gave this answer was: 'What would be the appropriate technology for Rural India or Rural Latin America or maybe the City slums?' Now it may well be that for a comparatively rural, primitive society, intermediate technology (rather than a sudden forced transformation to high technology) may be the answer. But we are neither a primitive society nor all city slums.

The situation in the United Kingdom is indeed almost the complete reverse. The Industrial Revolution started here and we have already gone further along the road of industrial success and then apparent rigidity and relative decline than any other country. What can we do? How can we combine our present state of industrial homeostasis with an enlightened approach? The clue must surely lie in our difficulty in seeing that size and technological/managerial efficiency are not the same, or at any rate are not hopelessly interlocked. The arguments against an undue concern with size (except in certain parts of the economy) are strong. The arguments in favour of applying modern technological and managerial control techniques are equally strong. What this book is concerned to show is that in a free-thinking, democratic society it is possible to use sophisticated, sometimes highly quantitative, techniques in the control of small businesses without impairing those special characteristics of a small business which we (and particularly those who work in it) admire so much.

This book therefore develops the theme that small business is beneficial, that it is flexible, that it can adapt to new situations more easily than large corporations, that it is innovative, that it already probably makes a larger contribution pro rata than large business, and that with efficient control and management techniques the benefit it gives can be much greater.

We do not use the words 'small' or 'smaller' here or throughout in any tight restrictive sense. We define a small business in the introductory chapter, but our definition includes what would often be called medium or medium small businesses. We are not trying to keep businesses small. We are seeking to make small businesses more effective and efficient in the very broadest senses (at one extreme this does include human aspects such as job satisfaction). In many cases increase in efficiency may mean growth. There is nothing wrong with this. All we are arguing here is that size does not necessarily lead to efficiency. More precisely efficiency comes as the result of making good decisions and implementing them properly.

This book concentrates on decisions and the provision of the information needed to make sensible decisions. In Part I the 
background for setting up a small business in the UK economy is explored. Part II is concerned with the financing of the venture. In Part III the accounting information and systems needed for proper decision-making are considered in some detail. Part IV deals with the use of such information in making decisions in areas such as the control of working capital and the appraisal of capital investment projects. Part V looks at the future and makes some suggestions as to the proper role of the small business in our society.

A number of American terms are now widely used in the United Kingdom. Although these terms are explained in the text when they first occur, it is helpful for ease of reference to have the US and the (virtually) equivalent UK terms set out. Thus:

\begin{tabular}{ll}
\multicolumn{1}{c}{ USA } & \multicolumn{1}{c}{ UK } \\
Income statement & $=\begin{array}{l}\text { Profit-and-loss account } \\
\text { (for current year's activities) }\end{array}$ \\
Accounts receivable & $=$ Debtors \\
Accounts payable & $=$ Creditors \\
Inventory & $=$ Stock \\
Bonds & $=$ (Unsecured) debenture loans
\end{tabular}

The 1981 Companies Act introduced standard formats for balance-sheet and profit-and-loss accounts. As we note in Chapter 1, these standard formats are not mandatory except for large companies. Nevertheless, the persuasive effect of these formats is considerable, and in particular the terms they use are likely to find a general acceptance. In Chapter 7 these terms are explained in some detail. In general they follow traditional UK practice. However, they do standardise and innovate to some extent. Thus 'turnover' is used instead of sales, and 'ordinary activities' (all normal yearly activities except extraordinary items) is introduced.

We have had a great deal of help from colleagues and friends in the preparation of this book, and in such research as we were able to do. In particular we would like to thank Sue Burns for her patient reading of handwritten chapters and invaluable comments, Joan Dewhurst for help and support, Jenny Johnson and Shirley Clarke for typing, John Perrin for help in research, Bill Austin for practical advice and Barclays Bank International for debugging a number of chapters. We would also like to thank for their valuable help in the early stages of the book Pat Desmond and John Ormerod of the Small Business division of Arthur Andersen \& Co. and Lance Watson and John Oram of Lloyds Bank. 
Finally, in this book we may use sexist words and phrases, though only, we hope, where predominant usage sanctions it (an example would be 'businessman' rather than 'businessperson'). Throughout we ask readers to accept that 'he' or 'him' subsumes 'she' or 'her'. Otherwise, to put it bluntly, the book would be (even more!?) inordinately long.

May 1983

Jim Dewhurst

Paul Burns 